\title{
Halottvizsgálati bizonyítványok adatainak elemzése nem boncolt elhunytak esetén
}

\author{
Turzó Csaba dr. ${ }^{1}$ - Juhász Péter dr. ${ }^{2}$ - Papp Zoltán dr. ${ }^{3}$ - Szöllősi Zoltán dr. ${ }^{4}$ \\ ${ }^{1}$ Debreceni Egyetem, Általános Orvostudományi Kar, Klinikai Központ, Igazságügyi Orvostan, Debrecen \\ ${ }^{2}$ Borsod-Abaúj-Zemplén Megyei Kórház és Egyetemi Oktató Kórház, Patológiai Osztály, Miskolc \\ ${ }^{3}$ Heves Megyei Kormányhivatal, Népegészségügyi Főosztály, Eger \\ ${ }^{4}$ Semmelweis Egyetem, Általános Orvostudományi Kar, Igazságügyi és Biztosítás-orvostani Intézet, Budapest
}

\begin{abstract}
Bevezetés és célkitüzés: Három megyében vizsgálták a halottvizsgálati bizonyítványok kitöltését boncolásra került, valamint boncolásmellőzött elhunytak esetében, különös tekintettel az erôszakos halálesetekre. Módszer: A három megyében valamennyi, 2006 és 2010 között bekövetkezett halálesetet vizsgálták. A halottvizsgálati bizonyítványok tekintetében rögzítették az alapbetegséget, a közvetlen halálokot, a halálozás jellegét, valamint a halottvizsgálatot kitöltő orvos kapcsolatát a halálesettel. Eredmények: A boncolások mellőzésének kérdésében a három megyében jelentős különbségek adódtak, attól függően, hogy ki töltötte ki a halottvizsgálati bizonyítványt. Az erőszakos halálesetek körébe sorolható baleseti jellegű halálozás esetén 844 esetben, nem meghatározott sérüléses mechanizmus esetén 28 esetben mellőzték a boncolást. Öngyilkosság esetén 25 esetben, emberölés tekintetében egy esetben nem került sor boncolásra. Köpetkeztetések: A magyarországi jogszabályok szerint minden olyan esetben, amikor a halál nem természetes vagy kétséges, hogy természetes úton állt be, hatósági vagy igazságügyi orvosi boncolást kell végezni. A halottvizsgálati bizonyítványok adatai alapján nem érthető, hogy erőszakos halálesetekben miért kerül sor a boncolás mellőzésére. Orv. Hetil., 2016, 157(52), 2082-2087.
\end{abstract}

Kulcsszavak: halottvizsgálat, nem természetes okú halál, boncolás, hatósági boncolás

\section{Analysis of death certificates in postmortem examination waivers}

Introduction and aim: The practices of autopsies and waivers in three Hungarian counties subject to the same statutory framework in a 5-year interval have been examined, with special attention to cases of non-natural death. Method: The summary data included in the post mortem examination certificates, for the years between 2006 and 2010 , in a breakdown according to counties, covering all cases of death were analysed. The work was assisted by a Java-based software programme. Results: In terms of the waiving of autopsies, a comparison of the three counties revealed significant differences. The persons who issue waivers from the performance of autopsies also vary across the counties. In case of deaths caused by accidents, no autopsy was performed in 844 cases. Similar situation was found in case of various identified and non-identified injuries, which were entered as the direct cause of death in 28 cases, as well as road traffic accidents entered in 32 cases and the unidentified consequences of road traffic accidents, which we found in 26 cases. No autopsy was performed in 25 cases of deaths assumed to be suicides and in one homicide. Conclusions: The Hungarian laws follow the recommendation of the Committee of Ministers to Member States of the Council of Europe, and provide that in all cases where the death is due to non-natural causes or the possibility of non-natural causes is raised, an autopsy should be performed. In this given legal context it is unclear how autopsies in the cases of death due to homicides, suicides and accidents as detailed above could possibly be dispensed with. The purpose of this paper was to provide a baseline study on the current practice of certification. The findings could be used in the course of governmental reviews for the purpose of drawing up recommendations.

Keywords: death certification, non-natural death, postmortem examination, medico-legal autopsy

Turzó, Cs., Juhász, P., Papp, Z., Szöllösi, Z. [Analysis of death certificates in postmortem examination waivers]. Orv. Hetil., 2016, 157(52), 2082-2087.

(Beérkezett: 2016. szeptember 12.; elfogadva: 2016. október 27.) 


\section{Rövidítések}

BNO = Betegségek Nemzetközi Osztályozása; HVB = halottvizsgálati bizonyítvány

A helyszíni halottvizsgálati eljárás, amelynek hagyománya a XII. századig nyúlik vissza, napjainkban is az orvos törvény által előírt kötelessége [1]. E halottvizsgálatot végezheti háziorvos, ügyeletes orvos vagy mentőorvos és halottvizsgálati szaktanácsadó [2]. A halottvizsgálati bizonyítványt (továbbiakban: HVB) a WHO által megadott forma szerint készítik el, az abban megjelölni kívánt betegségeknek meg kell felelniük a Betegségek Nemzetközi Osztályozása (BNO) által előírt rendszernek és követelményeknek (ICD-10) [3]. A halottvizsgálati bizonyítvány kitöltése jogilag dokumentálja a halál bekövetkeztét, adatokat szolgáltat epidemiológiai tanulmányokhoz, valamint meghatározza az egészségügyi kormányzat stratégiai tevékenységét is.

Az Európai Unió gyakorlatának megfelelően Magyarországon is a halálozásról HVB kerül kitöltésre, amely közokiratnak minősül [4]. A HVB az elhunyt személyes adatain kívül tartalmazza az alapbetegséget vagy állapotot, annak szövődményeként kialakult kórállapotokat, valamint a közvetlen halálokot. Ezek mellett adatot szolgáltat arra vonatkozóan is, hogy milyen volt a halálozás jellege, természetes, avagy erőszakos jellegü. A HVB alapján megállapítható, hogy történt-e boncolás, valamint arra vonatkozóan is információ nyerhető, hogy patológus, kezelőorvos vagy más orvos szolgáltatta az adatokat.

Vizsgálatunk során azonos jellemzők figyelembevételével elemeztük három magyarországi megye boncolási, illetve boncolásmellőzési gyakorlatát ötéves intervallumban, különös tekintettel a rendkívüli halálesetekre.

\section{Módszer}

\section{Adatgyüjtés}

A megfelelő engedélyek beszerzése után a Központi Statisztikai Hivatal (Budapest, Magyarország) adatbázisából beszereztük az összesített, megyékre bontott, 2006 és 2010 között bekövetkezett valamennyi haláleset halottvizsgálati bizonyítványán szereplő adatokat. Ezt követően azt vizsgáltuk, hogy Borsod-Abaúj-Zemplén, Hajdú-Bihar és Szabolcs-Szatmár-Bereg megyékben, 2006-2010 közötti időszakban, mennyi haláleset volt és ebből hány esetben mellőzték a boncolást. Értékeltük, hogy kik végezték a halottvizsgálati bizonyítványok kitöltését. Külön elemeztük azt, hogy a halottvizsgálati bizonyítványon feltüntetett alapbetegség/állapot és a közvetlen halálok között logikai kapcsolat fennáll-e, valamint vizsgáltuk azt, hogy a kódoló orvos szerint a haláleset milyen körülmények között következett be. Egyetlen halálesetet sem zártunk ki a vizsgálatunkból. A kódolt diagnózisokat két, patológia és igazságügyi orvostan szakvizsgával is rendelkező orvos tekintette át.

\section{Természetes kórokú, boncolásra nem került elhunytak adatai}

A boncolásra nem került elhunytak esetén vizsgáltuk a HVB-k alapbetegségre és közvetlen halálokra vonatkozó megállapításait, azaz a kitöltés minőségét. Lényeges szempont volt, hogy ezen adatok alapján fennáll-e közvetlen ok-okozati összefüggés a megjelölt alapbetegség és a közvetlen halálok között. Ennek részletes elemzésére három csoportot hoztunk létre:

Az első (tisztázott) csoportba azok az esetek kerültek, amelyeknél az alapbetegség és a közvetlen halálok között megfelelő ok-okozati kapcsolat volt megállapítható.

A második (kérdéses) csoportba azok az esetek kerültek, ahol csak a halál okáról kaptunk információt, az alapbetegségről nem. Ezt a csoportot hívhatnánk kódolási hiba csoportnak is, mivel alapbetegségként és halálokként is gyakran ugyanaz a kód volt feltüntetve.

A harmadik (értékelhetetlen) csoportba azok az esetek kerültek, amelyeknél a feltüntetett kódolás alapján sem a közvetlen halálok, sem pedig az alapbetegség nem volt megállapítható.

\section{Boncolásra nem került rendkíüli balálesetek}

Azokban az esetekben, ahol a boncolástól eltekintettek és a HVB adatai alapján rendkívüli halál következett be, vizsgáltuk a halálozás jellegét (baleset, öngyilkosság, emberölés), illetve a leggyakoribb halálokokat, valamint a halál bekövetkeztének körülményeit.

\section{Szoftverfejlesztés}

Munkánkat egy saját fejlesztésü Java alapú program segítette elő, amely az alapbetegségek és elsődleges halálokok BNO-kódjait kezeli. A program képes felismerni és kategorizálni az egyes alapbetegség-elsődleges halálok kódpárokat. A program múködése a mesterséges intelligencia elvén alapszik, adatbázisa a manuálisan, patológus és igazságügyi orvos szakértő által csoportosított kódpárok alapján folyamatosan bővíthető, így a program egyre több kódpárt ismer fel és képes csoportosítani. A program használata megakadályozza, hogy egy alapbetegség elsődleges halálok kódpár egyszerre két kategóriában szerepeljen, például ugyanaz a kódpár a kérdéses vagy az ellentmondásos csoportba kerüljön. A szoftver ez esetben hibaüzenetet küld, így könnyen eldönthető, hogy az adott esetet végül melyik csoportba szeretnénk helyezni. A szoftver továbbá megszüntette a manuális munkából származó pontatlanságokat is, valamint nem utolsósorban a munkavégzés sebességét is fokozta. A szoftver alapvetően két kezelőfelületet tartalmaz, amelyek közül az egyik a „kombinációk kezelése”. Itt arra nyílik lehetőség, hogy alapbetegség, illetve elsődleges halálok kódkombinációkat manuálisan, egyesével, vagy több kód- 
kombinációt, listából adjunk hozzá a megfelelő kategória adatbázisához. Ezen túlmenően lehetőségünk van törölni is az egyes kategóriák adatbázisában szereplő kódpárok közül. A másik kezelőfelület a „kategorizálás” menüpont alatt található, amely arra hivatott, hogy a kategorizálni szánt listában szereplő alapbetegség-elsődleges halálok kódpárokat az adatbázisában szereplő információk alapján szétválogassa és azt (a munkánk során használt három kategória szerint) három fájlban megjelenítse. A fel nem ismert kódmintázatok egy külön fájlba kerülnek, amelyet manuális feldolgozás után hozzáadhatunk az adatbázishoz. Így a munka során minden egyes alkalommal taníthatjuk a programot, bóvíthetjük az adatbázisát, ily módon könnyítve meg a munkát.

\section{Eredmények}

2006 és 2010 között a három vizsgált magyarországi megyében összesen 116074 haláleset történt, amelyek közül 67883 esetben nem végeztek boncolást. Az egyes megyék között a boncolás mellőzése tekintetében jelentős különbség mutatkozik. Borsod-Abaúj-Zemplén megye esetében folyamatosan emelkedő boncolási ráta látható (40\%-ról 50\%-ra). Hajdú-Bihar megye esetében 50 és 56\% között mozgott ez az érték, míg Szabolcs-Szatmár-Bereg megyében $20 \%$ körül volt (1. táblázat).
A HVB kitöltésében közremúködők megyéről megyére változnak, függetlenül attól, hogy történt-e boncolás, avagy sem. Borsod-Abaúj-Zemplén megyében a patológusok elenyésző számban mellőzik a kórboncolást, a halottvizsgálati bizonyítvány kitöltését (0-5\%), míg ugyanez az arány Szabolcs-Szatmár-Bereg megyében 39-55\% között ingadozik (2. táblázat).

\section{A halottvizsgálati bizonyitvány alapbetegségre és közvetlen halálokra vonatkozó adatainak vizsgálata boncolásra nem került elhunytaknál}

A tisztázott, egyértelmú ok-okozati összefüggést mutató esetek Borsod-Abaúj-Zemplén megyében 38-42\% között alakultak, míg a kérdéses csoportba az esetek mintegy 50\%-a volt sorolható (48-52\%). Az értékelhetetlen halottvizsgálati bizonyítványok aránya $5-12 \%$ volt.

Hajdú-Bihar megyében az első csoportba sorolható esetek aránya 38-41\%, a kérdéses esetek 49-54\%-ot képviseltek. Az értékelhetetlen esetek 5-9\% között mozogtak.

Szabolcs-Szatmár-Bereg megyében a tisztázott esetek 41-45\% között változtak, a kérdéses esetek 46-50\%-ot tettek ki. Az értékelhetetlen csoport 6-9\% között alakult (3. táblázat).

1. táblázat |A boncolások arányának évek szerinti bontása

\begin{tabular}{|c|c|c|c|c|c|c|}
\hline \multirow[t]{3}{*}{ Év } & \multicolumn{6}{|c|}{ Boncolási arányok } \\
\hline & \multicolumn{2}{|c|}{ Borsod-Abaúj-Zemplén megye } & \multicolumn{2}{|c|}{ Hajdú-Bihar megye } & \multicolumn{2}{|c|}{ Szabolcs-Szatmár-Bereg megye } \\
\hline & Boncolás & Boncolás mellőzése & Boncolás & Boncolás mellőzése & Boncolás & Boncolás mellőzése \\
\hline 2006 & $3981(40 \%)$ & $5850(60 \%)$ & $3402(50 \%)$ & $3452(50 \%)$ & $1393(20 \%)$ & $5446(80 \%)$ \\
\hline 2007 & $4276(43 \%)$ & $5648(57 \%)$ & $3855(56 \%)$ & $3023(44 \%)$ & $1523(22 \%)$ & $5341(78 \%)$ \\
\hline 2008 & $4276(45 \%)$ & $5240(55 \%)$ & $3692(54 \%)$ & $3108(46 \%)$ & $1472(22 \%)$ & $5373(78 \%)$ \\
\hline 2009 & $4590(48 \%)$ & $4894(52 \%)$ & $3552(54 \%)$ & $3034(46 \%)$ & $1563(23 \%)$ & $5146(77 \%)$ \\
\hline 2010 & $4834(50 \%)$ & $4876(50 \%)$ & $3450(52 \%)$ & $3129(48 \%)$ & $1459(22 \%)$ & $5196(78 \%)$ \\
\hline
\end{tabular}

2. táblázat |A halottvizsgálati bizonyítványt kitöltő orvosok megoszlása

\begin{tabular}{|c|c|c|c|c|c|c|c|c|c|}
\hline \multirow[t]{3}{*}{ Év } & \multicolumn{9}{|c|}{ Mellőzött esetek } \\
\hline & \multicolumn{3}{|c|}{ Borsod-Abaúj-Zemplén megye } & \multicolumn{3}{|c|}{ Hajdú-Bihar megye } & \multicolumn{3}{|c|}{ Szabolcs-Szatmár-Bereg megye } \\
\hline & Patológus & Kezelőorvos & Egyéb orvos & Patológus & Kezelőorvos & Egyéb orvos & Patológus & Kezelőorvos & Egyéb orvos \\
\hline 2006 & $\begin{array}{l}19 \\
(0,32 \%)\end{array}$ & $\begin{array}{l}3708 \\
(63,38 \%)\end{array}$ & $\begin{array}{l}2123 \\
(36,29 \%)\end{array}$ & $\begin{array}{l}882 \\
(25,55 \%)\end{array}$ & $\begin{array}{l}1496 \\
(43,34 \%)\end{array}$ & $\begin{array}{l}1074 \\
(31,11 \%)\end{array}$ & $\begin{array}{l}2501 \\
(45,92 \%)\end{array}$ & $\begin{array}{l}2054 \\
(37,72 \%)\end{array}$ & $\begin{array}{l}891 \\
(16,36 \%)\end{array}$ \\
\hline 2007 & $\begin{array}{l}152 \\
(2,69 \%)\end{array}$ & $\begin{array}{l}3132 \\
(55,45 \%)\end{array}$ & $\begin{array}{l}2364 \\
(41,86 \%)\end{array}$ & $\begin{array}{l}411 \\
(13,60 \%)\end{array}$ & $\begin{array}{l}1596 \\
(52,80 \%)\end{array}$ & $\begin{array}{l}1016 \\
(33,61 \%)\end{array}$ & $\begin{array}{l}2251 \\
(42,15 \%)\end{array}$ & $\begin{array}{l}2191 \\
(41,02 \%)\end{array}$ & $\begin{array}{l}899 \\
(16,83 \%)\end{array}$ \\
\hline 2008 & $\begin{array}{l}84 \\
(1,60 \%)\end{array}$ & $\begin{array}{l}3029 \\
(57,81 \%)\end{array}$ & $\begin{array}{l}2127 \\
(40,59 \%)\end{array}$ & $\begin{array}{l}665 \\
(21,40 \%)\end{array}$ & $\begin{array}{l}1302 \\
(41,89 \%)\end{array}$ & $\begin{array}{l}1141 \\
(36,71 \%)\end{array}$ & $\begin{array}{l}2116 \\
(39,38 \%)\end{array}$ & $\begin{array}{l}2267 \\
(42,19 \%)\end{array}$ & $\begin{array}{l}990 \\
(18,43 \%)\end{array}$ \\
\hline 2009 & $\begin{array}{l}150 \\
(3,06 \%)\end{array}$ & $\begin{array}{l}2712 \\
(55,41 \%)\end{array}$ & $\begin{array}{l}2032 \\
(41,52 \%)\end{array}$ & $\begin{array}{l}778 \\
(25,64 \%)\end{array}$ & $\begin{array}{l}1070 \\
(35,27 \%)\end{array}$ & $\begin{array}{l}1186 \\
(39,09 \%)\end{array}$ & $\begin{array}{l}2230 \\
(43,33 \%)\end{array}$ & $\begin{array}{l}1969 \\
(38,26 \%)\end{array}$ & $\begin{array}{l}947 \\
(18,40 \%)\end{array}$ \\
\hline 2010 & $\begin{array}{l}251 \\
(5,15 \%)\end{array}$ & $\begin{array}{l}2558 \\
(52,46 \%)\end{array}$ & $\begin{array}{l}2067 \\
(42,39 \%)\end{array}$ & $\begin{array}{l}824 \\
(2,33 \%)\end{array}$ & $\begin{array}{l}1120 \\
(35,79 \%)\end{array}$ & $\begin{array}{l}1185 \\
(37,87 \%)\end{array}$ & $\begin{array}{l}2848 \\
(54,81 \%)\end{array}$ & $\begin{array}{l}1445 \\
(27,81 \%)\end{array}$ & $\begin{array}{l}903 \\
(17,38 \%)\end{array}$ \\
\hline
\end{tabular}


3. táblázat |A mellőzött esetekben az alapbetegség és közvetlen halálok összefüggései

\begin{tabular}{llll}
\hline Év & \multicolumn{3}{l}{ Borsod-Abaúj-Zemplén megye } \\
\cline { 2 - 4 } & Tisztázott & Kérdéses & Ellentmondásos \\
\hline 2006 & $2467(42 \%)$ & $3092(53 \%)$ & $291(5 \%)$ \\
2007 & $2154(38 \%)$ & $2964(52 \%)$ & $530(10 \%)$ \\
2008 & $2124(41 \%)$ & $2538(48 \%)$ & $578(12 \%)$ \\
2009 & $1981(40 \%)$ & $2390(49 \%)$ & $523(11 \%)$ \\
2010 & $2016(41 \%)$ & $2418(50 \%)$ & $442(9 \%)$ \\
\hline
\end{tabular}

\begin{tabular}{llll}
\hline Év & \multicolumn{3}{l}{ Hajdú-Bihar megye } \\
\cline { 2 - 4 } & Tisztázott & Kérdéses & Ellentmondásos \\
\hline 2006 & $1570(45 \%)$ & $1691(49 \%)$ & $191(5 \%)$ \\
2007 & $1173(39 \%)$ & $1576(52 \%)$ & $274(9 \%)$ \\
2008 & $1179(38 \%)$ & $1639(53 \%)$ & $290(9 \%)$ \\
2009 & $1162(38 \%)$ & $1636(54 \%)$ & $236(8 \%)$ \\
2010 & $1286(41 \%)$ & $1596(51 \%)$ & $247(8 \%)$ \\
\hline
\end{tabular}

\begin{tabular}{llll}
\hline Év & \multicolumn{3}{l}{ Szabolcs-Szatmár-Bereg megye } \\
\cline { 2 - 4 } & Tisztázott & Kérdéses & Ellentmondásos \\
\hline 2006 & $2407(44 \%)$ & $2703(50 \%)$ & $336(6 \%)$ \\
2007 & $2236(42 \%)$ & $2630(49 \%)$ & $475(8 \%)$ \\
2008 & $2216(41 \%)$ & $2644(49 \%)$ & $513(9 \%)$ \\
2009 & $2305(45 \%)$ & $2363(46 \%)$ & $478(9 \%)$ \\
2010 & $2315(45 \%)$ & $2399(46 \%)$ & $482(9 \%)$ \\
\hline
\end{tabular}

\section{Rendkivïli halálesetek elöfordulása nem boncolt esetekben}

A vizsgált, boncolásra nem került esetek kapcsán 67883 $(98,73 \%)$ esetben természetes közvetlen halálok került megjelölésre a halottvizsgálati bizonyítványokon. Baleset okozta halálozás esetén 844 esetben nem történt boncolás, itt a leggyakoribb kódolási adat a különböző típusú megjelölt és meg nem jelölt esés, amelyeket a könnyebb áttekinthetőség kedvéért összevontunk egy csoportba, így összesen 696 esetet kaptunk. Hasonlóan jártunk el a különböző megjelölt és meg nem jelölt sérülések esetén is, amely 28 esetben szerepel közvetlen halálokként, míg közlekedési balesetet 32 esetben, baleset külön meg nem jelölt következményeit 26 esetben találtuk meg. Az egyes mérgezéses, robbanásos stb. esetekre külön nem térünk ki, mivel ezek kódolási gyakorisága $1 \%$ alatti.

Vélhetően öngyilkosságot elkövetôknél 25 esetben $(0,04 \%)$ nem történt boncolás. Az öngyilkosság módjai: 11 önakasztás, négy önkezú szúrás-vágás, három magasból történő leugrás, három esetben nyugtató- és altatószer-mérgezés, négy esetben pontosan meg nem határozható önártalom szerepelt.
Emberölésnél egy esetben nem történt boncolás, ahol a halottvizsgálati bizonyítvány közelebbről meg nem jelölt testi sértésre utalt.

\section{Megbeszélés}

A kórházakban, illetve a közterületen elhaltak kórboncolására vonatkozó szabályokat az egészségügyről szóló törvény tartalmazza Magyarországon. A főszabály az, hogy az elhunyt személyt, függetlenül attól, hogy egészségügyi intézményben vagy azon kívül hunyt el, kórbonctani vizsgálat alá kell vetni, ha a következő állítások bármelyike fennáll:

- a halál oka klinikai vizsgálatokkal nem volt megállapítható,

- perinatális halálozás esetén,

- az elhunyt szervátültetés donora vagy recipiense volt,

- az elhunyt foglalkozási eredetú megbetegedésben szenvedett és annak gyanúja merült fel - 1. 1997. évi CLIV tv. 219. $\$$. (1) d), hogy a halál oka ezzel van összefüggésben,

- az elhunyt szervezetében újra felhasználható, nagy értékü múszer található - amennyiben az nem képezi az elhunyt tulajdonát -, kivéve, ha a mûszer vagy eszköz jellege nem kívánja meg az elhunyt kórbonctani vizsgálatát, vagy az elhunyt még életében vagy a hozzátartozója a halál után kérte a kórboncolást, illetve, ha az esetnek tudományos vagy oktatási jelentősége van,

- az elhunytat hamvasztani kívánják.

Az utolsó két esetben el lehet tekinteni a boncolástól, ha a boncolás mellőzésének törvényi feltételei együttesen fennállnak:

a) a halál természetes eredetû,

b) a halál oka egyértelmúen megállapítható,

c) a kórbonctani vizsgálattól további lényeges megállapítás nem várható,

d) fekvőbeteg-gyógyintézetben elhunyt esetén a kezelőorvos és a patológus szakorvos, fekvőbeteg-gyógyintézeten kívül elhunyt esetén a kezelőorvos a kórbonctani vizsgálatot nem tartja szükségesnek, és az elhunyt még életében vagy a hozzátartozó írásban kérte a boncolás mellőzését [1].

Vizsgálatunkban három egymással szomszédos, hasonló népességgel, illetve népegészségügyi problémákkal jellemezhető megye boncolási és boncoláselengedési gyakorlatát elemeztük a fentiekben részletezett törvényi szabályozás keretein belül, de vizsgált esetszám alapján tanulmányunk alkalmas lehet arra, hogy országosan is érvényes következtetéseket vonjunk le belőle.

Amíg Borsod-Abaúj-Zemplén és Hajdú-Bihar megyékben konstansan az elhunytak közel fele kórboncolásra került, addig Szabolcs-Szatmár-Bereg megyében ez az arány $20 \%$-ot alig meghaladó. A különbség okai helyi tényezőkben keresendők, amelybő́l elsősorban a boncolások elengedésének eltérő kórházi és háziorvosi gyakorlata merül fel. Ugyancsak eltérő gyakorlatra utal az, hogy a boncolások elengedését ebben az utóbbi megyében 
patológus szakorvos dokumentálta az esetek 39-55\%ában.

A kérdés elemzéséhez fontos azt megemlíteni, hogy a kórboncolások száma világszerte csökkenő tendenciát mutat. Az Európai Unió államaiban a '90-es évek, valamint napjaink boncolási rátái között jelentős különbségek mutatkoznak. Ezek közül kiemelhető Dánia, ahol ez az érték az 52\%-os boncolási arányról 8\%-ra csökkent [5-8]. Ugyanebben az időszakban a kelet-európai államokban a boncolási arány átlagosan 10\%-kal magasabb volt, mint a nyugat-európai államokban. Magyarországon a '90-es években átlagosan az elhunytak 90\%-át boncolták fel, amely érték 1995-re 35\%-ra csökkent. A 2005 utáni években átfogó elemzés nem készült. Ha a legutóbbi, 1995-ben leírt értékhez viszonyítunk, a Hajdú-Bihar és Borsod-Abaúj-Zemplén megyében elvégzett boncolások aránya az országos átlag feletti, a SzabolcsSzatmár-Bereg megyében megtörtént boncolások aránya az országos átlag alatti. Ebben szerepet játszhat az, hogy Hajdú-Bihar megyében a Debreceni Egyetem miatt oktatási célból nagyobb számban végeznek kórboncolásokat, valamint az is, hogy szintén az egyetem miatt ennek a megyének a legjobb a patológus szakorvosi ellátottsága. Borsod-Abaúj-Zemplén és Szabolcs-Szatmár-Bereg megyében kevesebb patológus dolgozik, ez lehet a magyarázata annak, hogy Szabolcs-Szatmár-Bereg megyében a boncolások mellőzésére irányuló tendencia észlelhető. Ugyanakkor továbbra is kérdés, hogy önmagában ez vagy egyéb feltáratlan tényezók indokolhatják a boncolások számának jelentős különbségeit.

A boncolásra nem került esetekben megfelelően kitöltött halottvizsgálati bizonyítványt 38-45\%-ban találtunk, a fennmaradó esetekben kódolási hiba merült fel a halottvizsgálati bizonyítvány adatai alapján, amely mellett 5-12\%-ban teljesen értelmezhetetlen kitöltés történt. A bizonyítvány kiállítása során számos hiba fordulhat elő, így még mindig találkozunk rövidítések használatával - ez továbbra sem elfogadható. A formanyomtatvány jogszerú és helyes kitöltéséhez szükséges annak helyes értelmezése, ehhez a kísérő szöveg - a HVB hátoldalán segítséget nyújt. Sok orvos hiányos ismeretekkel rendelkezik a halottvizsgálati bizonyítvány kitöltésére és a betegségek kódolására vonatkozóan, néhányuk pedig tapasztalatlan vagy kevés gyakorlattal rendelkezik e téren [9-13]. Elöírás szerint a bizonyítványt szakorvosnak vagy más felelős beosztású orvosnak kell kitöltenie, ez a feladat csak akkor hárítható rezidensre, amennyiben megfelelő szakorvosi felügyelet biztosított. Ennek ellenére továbbra is szokás a HVB kitöltésével az orvosi csapat tapasztalatlanabb tagjait megbízni [14].

A frissen végzett orvosok a graduális képzés keretében V. évfolyamon kaptak információt a HVB kitöltésére vonatkozóan, jellemzően az igazságügyi orvostani képzés során. Tapasztalataink azt mutatják, hogy a graduális oktatás, valamint a számonkérés ellenére is, az orvosok egy része hiányos képzettséggel kerül ki az egyetemről a halottvizsgálati bizonyítványok kiállítása terén, ami az ok- tatás nem kellő hatékonyságára is utalhat. Megemlítjük azonban, hogy nemzetközileg a magyarországi halottvizsgálati bizonyítványokkal kapcsolatban 5-10\%-kal kedvezőbb eredményt mutató országok esetén önmagában az oktatás forszírozása, a számonkérés szigorítása sem graduális, sem posztgraduális szinten nem hozott kielégítő eredményt. Sokkal jobb eredmények érhetők el helyi minőségbiztosítási eljárásokon belül alkalmazott auditokon, ahol a hiányosságok kellően feltárásra kerülhetnek és orvosolhatókká válnak [15, 16]. Ettől függetlenül javasolható, hogy a hazai orvostudományi egyetemek egységesítsék a halottvizsgálattal kapcsolatos oktatási tananyagaikat, valamint a számonkérés módját.

Külön kiemelnénk azonban azt, hogy a rendelkezésünkre álló adatokból nem tudtunk arra vonatkozóan következtetést levonni, hogy mi magyarázhatja azt a statisztikai adatot, hogy azon megyében, ahol patológus szakorvos releváns módon részt vesz a nem boncolt elhunytak esetén a HVB-k kitöltésében, a „kérdéses” és „értékelhetetlen” bizonyítványok teljes aránya gyakorlatilag egyezik azon megyék adataival, ahol elsődlegesen nem kórboncnokok vesznek részt ebben a folyamatban.

Ismételten aláhúzzuk, hogy a HVB közokirat, amelynek megfelelő kitöltéséért az érintett orvos büntetőjogi felelősséggel is tartozik. Ennek fényében érthetetlen, hogy ha az elhunyt betegségével kapcsolatos orvosi dokumentumok a HVB kitöltésekor ismertek, vagyis az információ rendelkezésre áll, miért nem kerül rá, vagy miért nem megfelelően kerül a halottvizsgálati bizonyítványba.

A fentiekben leírtaknak megfelelően külön említést érdemel az a 7-12\%-ot elérő csoport, amely egyértelmúen értékelhetetlen információkat tartalmaz. Ennek alapján kizárólag a HVB adatait tekintve a haláleset nem rekonstruálható. E csoportban az eljáró orvosok gyakorlata szakmai hibának minősül és felveti a büntetőjogi felelősség kérdését is. Megemlítjük, hogy hasonló okokból indult jogi eljárások ismeretesek a szakirodalomban [17-19].

Külön megemlítenénk, hogy az Európa Tanács minisztereinek ajánlása [4] egyértelmúen útmutatást ad a tagországok számára, hogy mi a teendő a nem természetes halálesetek helyszíni vizsgálatakor, valamint a hatósági és igazságügyi orvosi boncolások elvégzésekor. Az útmutatás egyértelmúen fogalmaz a nem természetes és feltételezhetően nem természetes halálesetek vonatkozásában, abban a tekintetben, hogy a boncolás elvégzése ajánlott. A magyarországi jogszabályok ezt az ajánlást követik, és rögzítik, hogy minden olyan esetben, amikor a haláleset nem természetes módon következik be, vagy annak bekövetkezte kapcsán felmerül a nem természetes halálok, hatósági vagy igazságügyi orvosi boncolást kell végezni.

Ezen jogi környezetben érthetetlen a fentiekben említett emberölés, öngyilkosságok, valamint baleseti jellegű halálesetekben a boncolás mellőzése. Mivel emberölés és öngyilkosság esetében rendőrségi helyszíni szemle történik, így a boncolások mellőzése súlyos jogi következményekkel járhat a HVB-t kitöltő orvos esetén. A baleseti 
haláloknál, a haláleset és a baleset között úgynevezett késői szövődmény(ek) bekövetkezte, azaz közvetett okokozati összefüggés teremthet kapcsolatot, amelynek tisztázása igazságügyi patológiai szakkérdés és nem a halottvizsgálatot végző orvos vagy a halottvizsgálati bizonyítványt kitöltő, akár patológus szakorvos kompetenciája.

Arra vonatkozóan, hogy ezekben az esetekben mi volt a pontos oka a boncolások mellőzésének, valamint, hogy a haláleset hatósági bejelentésre került-e, és ha igen, mi volt a hatóság álláspontja, a rendelkezésünkre álló adatokból nem volt információ nyerhető.

\section{Következtetések}

Elmondható, hogy a vizsgált magyarországi megyékben nincs egységes gyakorlat a boncolások mellőzésére. Nincs abban sem egységes álláspont, hogy a boncolás mellőzése esetén ki végezze el a halottvizsgálati bizonyítvány kitöltését. Aggodalomra okot adó a rendkívüli halálesetek boncolásának mellőzése, amely törvénysértő gyakorlatot valószínúsít. Célunk az volt, hogy adataink összehasonlítási alapot képezzenek jövőbeni változások nyomon követéséhez. Eredményeink rávilágítanak a jelenlegi gyakorlat hiányosságaira, így a halottvizsgálati eljárás helyes lefolytatását oktató szakemberek számára is hasznosnak bizonyulhatnak.

Anyagi támogatás: A szerzők anyagi támogatásban nem részesültek.

Szerzői munkamegosztás: T. Cs., J. P., P. Z.: Adatgyűjtés, adatelemzés. J. P.: Szoftverfejlesztés. T. Cs., J. P., P. Z., Sz. Z.: A vizsgálat tervezése, következtetések. A cikk végleges változatát valamennyi szerző elolvasta és jóváhagyta.

Érdekeltségek: A szerző́knek nincsenek érdekeltségeik.

\section{Irodalom}

[1] Act CLIV of 1997 on Health. [1997. évi CLIV törvény az egészségügyről.] http://net.jogtar.hu/jr/gen/hjegy_doc. cgi?docid=99700154.TV [Hungarian]

[2] Government Degree No. 351/2013, Paragraph 3, Sections 1 and 2. [351/2013. sz. kormányrendelet 3 . \$ (1) és (2) bekezdés.]
http://net.jogtar.hu/jr/gen/hjegy_doc.cgi?docid=Al30035l. KOR [Hungarian]

[3] International Statistical Classification of Disease and Related Health problems, 10th Revision, ICD-10. World Health Organization, Geneva, 1992.

[4] The recommendation of the Committee of Ministers to Member States of the Council of Europe [Recommendation No. R (99) 3]. http://www.coe.int/t/dg3/healthbioethic/texts_and_documents/RecR(99)3.pdf

[5] Anderson, R. E., Hill, R. B., Key, C. R.: The sensitivity and specificity of clinical diagnostics during five decades. Toward an understanding of necessary fallibility. JAMA, 1989, 261(11), 16101617.

[6] Davis, C. J.: Autopsy rates: the decline with age. PAS Rep., 1979, 16(18), 31-41.

[7] Abronheim, J. C., Bernholc, A. S., Clark, W. D.: Age trends in autopsy rates. Striking decline in late life. JAMA, 1983, 250(9), 1182-1186.

[8] Sinard, J. H.: Factors affecting autopsy rates, autopsy request rates, and autopsy findings at a large academic medical center. Exp. Mol. Pathol., 2001, 70(3), 333-343.

[9] Ashley, J. S.: Completion of medical death certificates cause of death. Office of Population Censuses and Surveys. HMSO, London, 1990.

[10] Maudsley, G., Williams, E. M.: Inaccuracy in death certification - where are we now? J. Public Health Med., 1996, 18(1), 59-66.

[11] Alderson, M. R, Bayliss, R. I., Clarke, C. A., et al.: Death certification. Br. Med. J., 1983, 287(6390), 444-445.

[12] James D. S., Bull, A. D.: Information on death certificates: cause for concern? J. Clin. Pathol., 1996, 49(3), 213-216.

[13] Slater, D. N.: Certifying the cause of death; an audit of wording inaccuracies. J. Clin. Pathol., 1993, 46(3), 232-234.

[14] Maudsley, G., Williams, E. M.: Death certification by house officers and general practitioners - practice and performance. J. Public Health Med., 1993, 15(2), 192-201.

[15] Pain, C. H., Aylin, P., Taub, N. A., et al.: Death certification: production and evaluation of a training video. Med. Educ., 1996, 30(6), 434-439.

[16] Weeramanthri, T., Beresford, W., Sathianathran, V.: An evaluation of an educational intervention to improve death certification practice. Aust. Clin. Rev., 1993, 13(4), 185-189.

[17] James, D. S., Bull, A. D.: Death certification: is correct formulation of cause of death related to seniority or experience? J. R. Coll. Physicians Lond., 1995, 29(5), 424-428.

[18] Medical aspects of death certification. A joint report of the Royal College of Physicians and the Royal College of Pathologists. J. R. Coll. Physicians Lond., 1982, 16(4), 206-218.

[19] Hanzlick, R.: Lawsuits against medical examiners or coroners arising from death certificates. Am. J. Forensic Med. Pathol., $1997,18(2), 119-23$. 